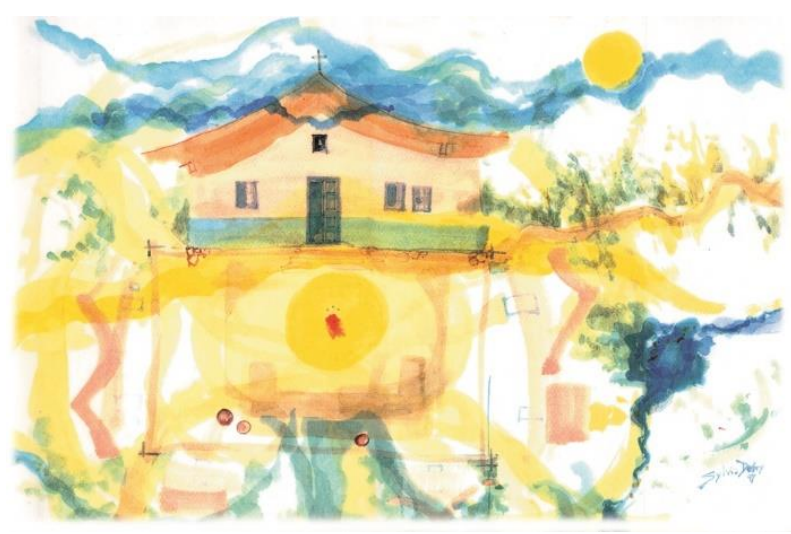

\title{
Participação, arte e vivências num território cultural
}

Participation, art and living in a cultural territory

\author{
Sylvia Adriana Dobry ${ }^{1}$ \\ Caio Boucinhas ${ }^{2}$ \\ Denise Falcão Pessoa ${ }^{3}$
}

Resumo: A experiência entre docentes da "Escola Esmeralda Becker" na Aldeia de Carapicuíba, e estudantes de pós-graduação da FAU- USP em 1997, cujos objetivos foram: atingir um estudo do meio interdisciplinar, com a arte como eixo principal; reconhecer o local, moradores, cotidiano, seus sonhos; preservar recursos naturais, história, cultura, e também desenvolver um projeto participativo urbano-paisagístico. O entrelaçamento dos processos criativos e seu rebatimento na produção artística individual colaboraram para a reflexão sobre apropriação e identidade. Expandiram- se horizontes de esperança na preservação histórica e ambiental e a implantação do projeto - hoje com o nome de Parque Ecológico da Aldeia de Carapicuíba - pela Prefeitura, só foi possível pela participação da comunidade

Palavras-chave: Arquitetura e urbanismo. Aldeia de Carapicuíba. Arte. Representação e participação. Abstract: This paper deals with the experience among teachers of the "Emerald Becker School" in "Aldeia de Carapicuíba" and graduate students from FAU-USP in 1997. The objectives were: to achieve an interdisciplinary environment study, being art the main axis: to recognize the site, the tenements and their dreams; to preserve natural resources, history, culture, and also develop a participatory urban-landscape project. The intertwining of creative processes and their bending with the individual artistic production collaborated for the reflection on appropriation and identity of the place. Expectations of hope in historical and environmental preservation have been expanded, and the implementation of the project - today called the Ecological Park of the Carapicuíba Village - by the municipality, was only possible through community participation.

Keywords: Architecture and urbanism. Cultural territories. Carapicuíba Village. Art. Representation and participation.

\footnotetext{
${ }^{1}$ Graduada em Arquitetura e Urbanismo pela Universidade Nacional de Córdoba (1969), Mestre em Estruturas Ambientais Urbanas (2002) e doutora em Arquitetura e Urbanismo pela USP (2008). Tem experiência na área de Arquitetura e Urbanismo e Artes Plásticas. Professora do Curso de Mestrado Profissional na área de Arquitetura e Urbanismo Projeto, Produção do Espaço Urbano na FIAM-FAAM, e na graduação na mesma instituição orienta o Escritório Modelo. E-mail: sydobry@gmail.com ORCID: https://orcid.org/0000-0002-8048-9592

${ }^{2}$ Professor do Mestrado Profissional área de Arquitetura e Urbanismo, Projeto, Produção do espaço Urbano na FIAMFAAM, Centro Universitário, e na graduação na mesma instituição orienta o Escritório Modelo. Pesquisador no Laboratório de habitação e assentamentos Humanos (LABHAB) da FAU-USP. Graduado em Arquitetura e Urbanismo pela UFMG (1967) e doutor em Arquitetura e Urbanismo pela FAU-USP. (2005). E-mail: cboucinhas@uol.com.br. ORCID: https://orcid.org/0000-0003-1285-5762

${ }^{3}$ Graduada em Arquitetura e Urbanismo pela Universidade Mackenzie (1979), mestre em Arquitetura e Urbanismo pela Universidade de Michigan, Estados Unidos (1982) e doutora em Estruturas Ambientais Urbanas pela FAU USP(2003) Professora do Mestrado Profissional área de Arquitetura e Urbanismo e Design do Centro Universitário Belas Artes de São Paulo e do Curso de Arquitetura e Urbanismo da UNINOVE. E-mail: denisefpessoa@ hotmail.com. ORCID: https://orcid.org/0000-0003-1828-9423
} 


\section{INTRODUÇÃO}

Foi concretizada em 1997 uma experiência conjunta, entre uma equipe de alunos/as de pós-graduação da USP, a maioria da FAU, arquitetos/as, sob a coordenação pedagógica da Profa. Dra. Nidia Nacib Pontuschka, da Faculdade de Educação (USP) e um grupo de professores/as e funcionários/as da "Escola Esmeralda Becker Freire de Carvalho", na Aldeia de Carapicuíba, São Paulo e seu entorno, sendo na época diretora da escola, Maria Helena Scabelo. O trabalho fazia parte da disciplina de pós-graduação "Projeto sensível, projeto tecnológico, suas relações". ${ }^{4}$

Nessa conjuntura, quando nos foi oferecido nessa disciplina de pós-graduação da FAU/USP a possibilidade de estudar um projeto para Aldeia de Carapicuíba e as mudanças que poderiam ocorrer, após a inauguração do anel viário metropolitano, realizaram se visitas ao local.

Constituída em 1580, a Aldeia de Carapicuíba é um dos 12 aldeamentos jesuíticos que restaram do processo de urbanização de São Paulo - criados para proteger essas cidades e domesticar os índios - no caso, Guaianases ${ }^{5}$. Falava-se a língua geral, ou tupi, desde o início da colonização, em São Paulo, em um espaço em que se concentravam os aldeamentos indígenas, com grande densidade de população, nos arredores da Vila. Só em 1758, a língua portuguesa foi implantada em São Paulo. (OLIVEIRA, 2005, p. 1)

A bacia de Carapicuíba compreende o ribeirão Carapicuíba e seus afluentes. A Avenida Inocêncio Seráfico é remanescente do caminho palmilhado pelos Guaianases que habitavam Carapicuíba, antes da chegada dos colonizadores portugueses. Estes índios, desviando-se do caminho de Cotia, desciam até o rio Tietê para pescar e banhar em suas águas. Em suas andanças, aí se estabeleceram, construindo uma taba com suas ocas, gérmen da atual Aldeia.

\footnotetext{
${ }^{4}$ A disciplina foi ministrada pelo professor Sylvio Sawaya , com a consultoria do arquiteto Caio Boucinhas, contratado pela prefeitura em 1994, para projetar um parque nesse sitio, e a equipe de alunos/asarquitetos/as formada por Denise Falcão Pessoa, Ely Ana de Oliveira Araujo, Paulo Chiesa, Regina Cardarelli e Sylvia Adriana Dobry-Pronsato .Também participaram, exceto Paulo Chiesa, na pesquisa sobre a Aldeia de Carapicuíba, realizada no Centro Universitário Nove de Julho, coordenada pela Profa. Dra. Maria José Feitosa, com consultoria do Prof. Dr. Sylvio Sawaia da FAU-USP e a participação, entre outros/as, do Prof.Dr. Carlos Eduardo Zahn, docente dessa universidade e também da FAU-USP, dos/as Profs. Eliana Quartim Barbosa, Luiz Otavio de Faria e Silva, Sergio Torres Moraes e dos arquitetos/as Maria de Lourdes Nogueira, Roberto Mello e Roberto Dantas Araujo.

5 Segundo João Barcellos, (2007,s/p.),"Guaianases são Guaranis". Disponível in: http://www.apagina.pt/?aba=7\&cat=173\&doc=13084\&mid=2 data acesso 24/06/2013.

${ }^{5}$ Houve na época um debate entre o IPHAm e a comunidade, por considerar se que os jerivás não pertenciam a época em que os jesuítas construíram a Aldeia e que tinham sido plantados posteriormente pelos Franciscanos. Assim, foram retirados da Praça, porém a pressão da comunidade, fez que posteriormente foram novamente plantados. Aqui se evidencia uma questão importante em torno do tema preservação: a discussão sobre que época se preserva.
} 
Importante ressalvar que a Aldeia de Carapicuíba é um marco arquitetônico e histórico da região metropolitana de São Paulo, fundada no século XVI, e caracterizada por construções remanescentes do século XVIII. É patrimônio histórico, declarado em 1941 pela Secretaria do Patrimônio Histórico e Artístico Nacional (SPHAN), avaliado como um exemplo único de aldeamento paulista jesuítico.

Seu valor está, principalmente, na organização espacial original definida por construções que apoiam sua volumetria em relação com o patrimônio jesuítico. Hoje em dia, é um monumento nacional importante, por simbolizar a memória do processo da colonização europeia na América. (ZAHN, C.; FEITOSA, M. J.; SAWAYA, S., 2008, p.136). Foi abandonada e, duas vezes, parcialmente destruída, entretanto reerguida no mesmo lugar.

Em 1997, observou se que as construções eram de taipa de sopapo, com exceção da igreja e algumas paredes das casas, de taipa de pilão; o pátio, retangular, de chão batido e inclinado como o terreno natural, é dominado pela igreja, erguida no meio da lateral mais elevada. Em frente à igreja, um plano horizontal com arrimos de pedra, dez palmeiras jerivá alinhadas em duas filas, da igreja até o cruzeiro; ao redor do pátio, as casas onde funcionavam, bares, mercearia, frutaria, farmácia, correio, a casa de cultura da Prefeitura, o posto policial, residências e vestíbulo de um restaurante. No entorno, mais residências, alguns sítios de fim de semana, três indústrias; à jusante do pátio passa o córrego Anhembi, poluído; à montante, atrás de muros altos, a área do antigo Sanatório Anhembi, com muita vegetação e águas límpidas. Todas as paredes das casas da Aldeia caiadas de branco com barra azul-claro e portas e janelas com seus batentes azuis-escuros; no pátio, postes, fio elétrico, ônibus, caminhões, carros, bicicletas.

À primeira visita, a aldeia nos pareceu silenciosa, sonolenta, perdida no tempo. Que segredos estariam ocultos naquele lugar perdido da história de São Paulo? Depois de passear pelos arredores adjacentes à aldeia, procuraram se informações. Descobriu se uma biblioteca e a Casa de Cultura, onde os funcionários indicaram a escola, onde a diretora recebeu o grupo. Ela narrou histórias do dia a dia, da vergonha que muitos sentem por serem considerados descendentes de índios, dos migrantes, das ruas de barro, das crianças, da vontade de crescer, das palmeiras nativas chamadas jerivás da praça que lá estavam e não estavam mais. ${ }^{6}$

\footnotetext{
${ }^{6}$ Houve na época um debate entre o IPHAm e a comunidade, por considerar se que os jerivás não pertenciam a época em que os jesuítas construíram a Aldeia e que tinham sido plantados posteriormente pelos Franciscanos. Assim, foram retirados da Praça, porém a pressão da comunidade, fez que
} 


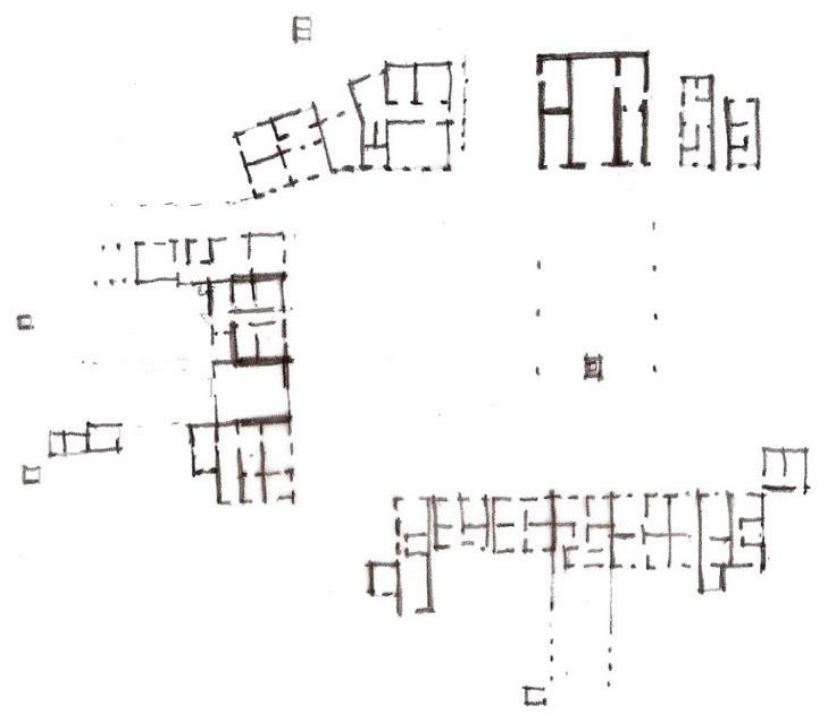

Figura 1. Croqui da Planta da Aldeia de Carapicuíba, realizado em lápis sobre papel por Sylvia A.Dobry/ 2017, com base nos estudos de Luis Saia. ${ }^{7}$

Deste modo nasceu a ideia dessa experiência, que era inicialmente acadêmica e acabou por estender-se para fora dessa fronteira, abraçando assim, um estudo para a implantação de um projeto participativo de revitalização urbana e paisagística do lugar, designado, naquele momento, como "Parque Ambiental Aldeia de Carapicuíba".

Sob o ponto de vista dos arquitetos alunos da pós-graduação, os objetivos mais relevantes deste projeto, consistiam em:

- Desenvolver um estudo do meio interdisciplinar, que incluía como eixo principal a arte.

- Reconstruir e resguardar a história, os recursos naturais e a cultura da Aldeia de Carapicuíba, o que abrangia conhecer o lugar e o que ele poderia revelar: moradores, suas ações no cotidiano e sonhos.

- Realizar um processo de projeto urbano-paisagístico participativo com alunos, professores e moradores da aldeia.

Os objetivos sob o ponto de vista dos professores da "EEPG Esmeralda Becker", eram:

- Fazer reflexões e debates entre professores de diferentes matérias, tendo o aluno como principal sujeito.

posteriormente foram novamente plantados. Aqui se evidencia uma questão importante em torno do tema preservação: a discussão sobre que época se preserva.

${ }^{7}$ Estudos gráficos de Luis Saia sobre Aldeia de Carapicuíba,podem ser consultados na Secretaria Regional do Iphan do Rio de Janeiro 
- Efetivação de um trabalho interdisciplinar, tendo consciência da história local, a partir do Estudo do Meio, que seria base para trabalhos com os alunos da escola.

\section{Estudo do Meio, Arte e Participação urbano-paisagística,}

Durante a primeira reunião na escola, ao iniciar as atividades, a Profa. Dra. Nidia Nacib Pontushka discorreu sinteticamente sobre o Estudo do Meio, gerado a partir das lutas anarquistas nos primeiros anos do século XX e que priorizava a observação direta da realidade, substituindo o aprendizado entre os muros da sala de aula. Aderindo a este método, permite-se a construção de uma configuração de ensino em que todos participam: alunos, diretores, professores, funcionários, pais, moradores e, dessa forma, evita-se que as instituições de ensino sejam percebidas de modo isolado. Esclareceu a professora que o Estudo do Meio, como método interativo, pode criar esperanças que nos fazem refletir sobre o retorno do projeto à comunidade.

É inegável a afinidade deste método de ensino com Paulo Freire (1997, p 16), que considerou os espaços da educação como relação interativa, que transcende o espaço formal e atinge o informal "na cidade que se alonga como educativa". Inspira a possibilidade de um entrelaçamento entre uma prática pedagógica interativa e dinâmica, e uma maneira de agir do arquiteto na sociedade, que dialoga e interage procurando construir um projeto participativo dos espaços, vendo o homem como um ser de relação “não apenas no mundo, mas com o mundo". (FREIRE, P., 1997, p 43). Ainda segundo o autor, a complexidade das

relações entre educação, enquanto processo permanente, e a vida das cidades, enquanto contextos que não apenas acolhem a prática educativa como prática social, mas também se constituem, através de suas múltiplas atividades, em contextos educativos em si mesmos. (FREIRE, P., 1997: 16)

Também se destaca a leitura da cidade, leitura tão necessária à ação do arquiteto quanto, entre outros profissionais, revela o olhar que

destrincha ou esmiúça a sua significação mais íntima, expressa ou explicita a compreensão do mundo, .... inteligência da vida na cidade, o sonho em torno desta vida, tudo isso grávido de preferências políticas, éticas, estéticas e urbanísticas de quem o faz. (FREIRE, P., 1997: 16) 
E no âmago do tema ensino e sua relação com projetos participativos, do mesmo modo, a pedagoga argentina Maria Saleme de Burnichon, ${ }^{8}$ um dos pilares pedagógicos do Taller Total da Faculdade de Arquitetura e Urbanismo, da UNC afirmou que:

Ensinar é aprender a escutar. [...] $\mathrm{O}$ valor do silencio no ensino o recuperei desde México. Têm que escutar muito. Porque há coisas que não se dizem, há linguagens aos que nos, com a nossa oralidade temos lhe tirado o peso vital que tem, o peso comunicacional. [....] Ensinar é estar atento ao gesto do outro". (BURNICHON, 1996)

Do Estudo do Meio interdisciplinar, cujo carro-chefe foi a arte, segundo a Profa. Nidia Nacib, enfatiza-se, sobretudo, entre as atividades realizadas, a de percepção do lugar através do desenho, e da qual falaremos com mais detalhes no decorrer do texto. Como resultado da inter-relação entre as diferentes maneiras de representar dos participantes, nesse contexto, houve transformações no processo criativo artístico individual de um dos autores/as deste artigo, como, aquarelista, desenhista e arquiteta. $\mathrm{O}$ entrelaçamento dos diversos processos criativos e sua expressão na produção artística individual, de nosso ponto de vista, contribui também para uma reflexão mais abrangente sobre os diversos territórios culturais e sua apropriação. Foram tentativas que contribuíram para a recuperação e reconstrução da identidade de um determinado lugar considerado patrimônio histórico.

Ao longo de um ano, se realizaram encontros entre os arquitetos/as participantes, outros/as profissionais, professores/as e funcionários/as da Escola, onde professores/as e alunos/as realizavam Estudos do Meio, transferindo os conhecimentos interdisciplinares surgidos nas reuniões à sala de aula. Nesses momentos, as questões do "lugar", entendido como "território cultural" foram surgindo e, entre outras, marcas e lendas da cultura indígena e jesuítica.

\footnotetext{
${ }^{8}$ María Esther Saleme de Burnichón (1919- 2003) foi uma das máximas referencias de educação em Argentina: despedida da Universidade Nacional de Córdoba, por ocasião do golpe de Onganía em 1966. Se exilou em México, onde foi investigadora da Universidade de Veracruz, em Xalapa, e realizou um trabalho de alfabetização de adultos em comunidades indígenas e escolas rurais; organizou também, nessa mesma universidade, a pós-graduação e participou da criação do Centro de Investigações Educativas (CIE). Voltando do exílio, nos anos 1970, foi um dos pilares pedagógicos do Taller Total da FAU-UNC e simultaneamente desenvolveu trabalhos de alfabetização em Salta (Argentina), em cuja Universidade dirigiu o Ano Básico Comum ABC, para ingressantes. Em 1976, se exilou novamente no México e só retornou à Argentina, reassumindo seu cargo na UNC, onze anos após. Desde 1988 a 1990 foi diretora da Faculdade de Filosofia da Universidade Nacional de Córdoba e Diretora do Centro de Investigação dessa faculdade, que hoje leva seu nome.

${ }^{9}$ Entrevista realizada a María Saleme de Burnichon em junho de 1996 e publicada no suplemento digital da revista "La Educación en nuestras manos" ( $\mathrm{N}^{\circ} 23$; setiembre de 2004), do Sindicato Unificado de Trabajadores da Educação d Provincia de Buenos Aires.
} 
Essa experiência de índole participativa vem confirmar a observação de Mayumi Sousa Lima sobre a importância dos espaços educativos como lugares que "as cidades paulistas oferecem universalmente como possibilidades de reconquista dos espaços públicos e populares [...] que as crianças e jovens perderam na cidade capitalista industrial. A reconquista requer o rompimento da escola - prisão - fortaleza e sua transformação na escola - praça - parque”. (LIMA, Mayumi Sousa, 1989, p.50).

O processo com a Escola Esmeralda Becker fertilizou a construção do conhecimento, tendo um papel essencial no intercâmbio de papeis - arquitetos/as usuários/as e aluno/a -professor/a.

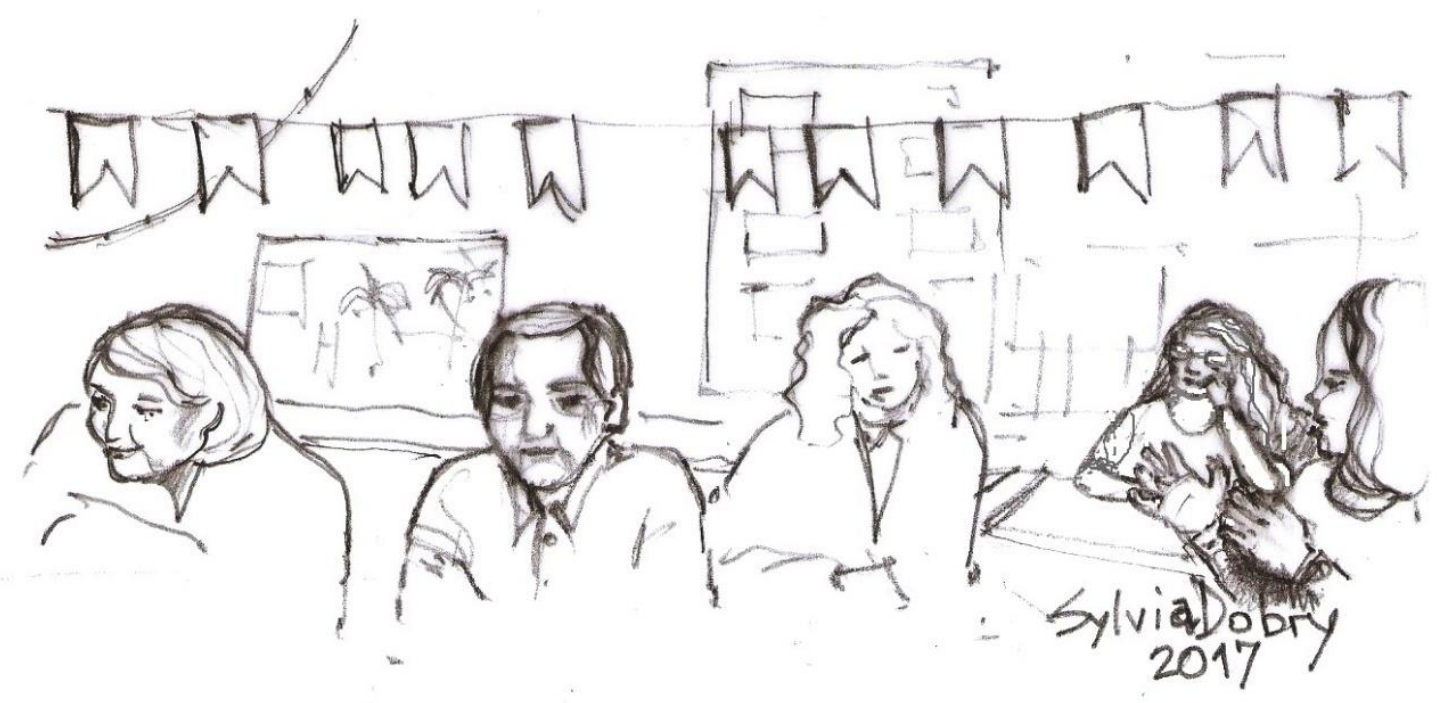

Figura 2. Croqui de reunião do Estudo do Meio na EEPG Professora Esmeralda Becker, com o historiador convidado, Miguel Costa Jr., morador da região. Desenho de lápis sobre papel realizado por Sylvia a. Dobry /2017, com base em fotografias de 1998, pertencente ao arquivo pessoal dos autores.

E interessante assinalar que este processo se insere num contexto geral em que, como aponta Perry Anderson, (1999: 102-103) a partir dos anos 1960-70 é marcado por alguns temas relevantes:

- Acentuam-se as mudanças ocorridas na percepção a partir do início do século XX, no contexto de enormes transformações urbanas e tecnológicas.

- O progresso e a indústria, vistos como avanços tecnológicos já não são vistos somente na sua dimensão positiva: mesmo se a ciência, trazendo o progresso, mostrasse a ameaça técnica dos instrumentos que criavam a morte, a destruição, incluindo explosões nucleares.

- É no período entre guerras que "glamour e velocidade tornaram-se, ainda mais que antes, as notas dominantes no registro da percepção”. Esta gestalt é mudada 
repentinamente na Segunda Guerra, com a chegada de máquinas que, lançavam sobre a experiência cotidiana uma sombra maligna.

- O rádio tornara possível a desconexão entre olho e ouvido e a TV consegue captar a atenção do público de uma maneira imensamente maior, porque não se trata simplesmente de audiência: antes de se aprumar o ouvido, o olho é atingido e o imaginário chega a um grau de saturação jamais antes atingido, especialmente com a chegada da televisão a cores, por volta dos anos de 1970.

Ao analisar que "das coisas ao pensamento das coisas, reduz-se a experiência" (MERLEAU-PONTY, [1945], 1994, p. 497), é necessário destacar a experiência do corpo como lugar criador de sentidos, já que a percepção não é só uma representação na mente, mas inclui toda a corporeidade e, como tal, a existência.

$\mathrm{O}$ anterior explica a importância que adquirem as atividades artísticas realizadas, nesse contexto, tanto especifico quanto geral, com fins de observação e documentação, objetivando o desenvolvimento da percepção, a partir das pesquisas de campo, entre as quais, salientamos fotografias de lugares e pessoas entrevistadas, desenhos, aquarelas, maquetes, poesias, processo que alimentou também a criatividade individual de cada um dos participantes. Isto porque considerou -se essencial atribuir relevância

[...] às narrativas esquecidas nesse contexto, à arte como possibilidade de legitimar memórias, de revistar lugares e revelar o que se quis esconder. [...] devolvendo á arte sua potência como organizadora do sensível e que também se alinha aos propósitos da filosofia benjaminiana de: "fazer a história dos sem história", "dar voz aos sem voz", erguer uma contra-historia. E com isso adentrar em territórios muitas vezes destituídos de imagens, de recordações, de campos simbólicos que se ancoram [...] no vazio, no apagamento. [...] nesse contexto, a arte se manifesta como criadora de campos do porvir, do imaginário e do simbólico [...] (GIANVECCIO, 2013:199-200)

Esses trabalhos foram concretizados tanto pelos participantes do Estudo do Meio, quanto pelos alunos da escola, orientados por seus professores. O produto dessas atividades foi apresentado em diversas exposições e em diferentes lugares da Aldeia, abertos à comunidade, como uma forma de devolução à sua generosidade em nos fornecerem dados para a elaboração do conhecimento, tanto da escola como da universidade participantes. 
Está implícita nesta abordagem as ideias de Beuys em relação a "arte ampliada", história vista como escultura e a sua afirmação de que a educação artística do ser humano é o que mais interessa. $\mathrm{O}$ autor e artista considera que

"a criatividade não é monopólio das artes. (...) Quando eu digo que toda a gente é artista eu quero dizer que cada um pode concentrar a sua vida nessa perspectiva: pode cultivar a artisticidade tanto na pintura como na música, na técnica, na cura de doenças, na economia ou em qualquer outro domínio... A nossa ideia cultural é muitas vezes redutora. O dilema dos museus e das instituições culturais é que limitam o campo da arte, isolandoa numa torre de marfim (...). O nosso conceito de arte deve ser universal, terá que ter uma natureza interdisciplinar com um conceito novo de arte e ciência" (BEUYS, [1979] - entrevista com Franz Hak. apud RODRIGUES, J. 2002, p.05).

Em metodologias participativas de projetos urbano - paisagísticas, como era este caso, que se entrelaçava com metodologias educativas também de teor crítico e participativo, a ideia ampliada da arte de Joseph Beuys contribui a fundamentar esta opção, em especial quando afirma que:

[...] o conceito de arte deve aplicar se ao trabalho humano; criatividade é uma habilidade humana, e por isto o conceito antropológico de arte refere-se as habilidades criadoras gerais [...]; o conceito ampliado de arte é uma formula básica do ser que todo transforma. (BEUYS, [1979]. Apud Stachelhaus, H., 1990, p.74).

Esta ideia de arte ampliada, conduz ao que Beuys designou como "escultura social”, na qual está implícita a relação antropológica da arte e criatividade vista como a ciência da liberdade.

Todo saber humano provêm da arte, o conceito de ciência se desenvolveu a partir do criativo. Assim, só o artista criou a consciência histórica. Por conseguinte, a história deve ser vista em forma plástica. A história é escultura. (BEUYS, [1979]. Apud Stachelhaus, H., 1990, p.74).

Quando Beuys diz que "cada homem é um artista", ele se refere à possibilidade de transformação do corpo social, e na que considera que todo ser humano pode e deve tomar parte "para que possamos realizar a transformação no menor tempo possível". (BEUYS, [1979]. Apud Stachelhaus, H., 1990, p.77).

No decorrer do processo na Aldeia de Carapicuíba esteve presente tanto a premissa de recuperar sua importância como patrimônio histórico, por ser símbolo das relações iniciais que a colonização portuguesa teve com os moradores indígenas da região, como também o respeito à sensação de fragilidade e delicadeza que a Aldeia provoca. 
Com base nesta experiência conjunta, a equipe de arquitetos/as - alunos/as de pósgraduação da FAU USP, da disciplina "Projeto sensível, projeto tecnológico, suas relações" - decidiu que continuaria a proposta de criação de um parque nesse sitio realizada pelo Arquiteto Caio Boucinhas, iniciado em 1994. Esse procedimento projetual foi considerado como uma experiência de projeto participativo e foi batizado, com o título de "Parque Ambiental Aldeia de Carapicuíba", e cujo nome mudou ao ser implantado, trocando-se a palavra Ambiental por Ecológico.

Em todo o tempo dedicado ao desenvolvimento desse projeto, procurou-se compreender o significado de uma intervenção urbano-paisagística, ponderando os paradoxos com que nos encontrávamos. Em especial, problemáticas com relação à população local, que poderiam aparecer com a implantação do projeto do parque no lugar, como, por exemplo, possibilidades de gentrificação.

Também, no transcorrer das reuniões, foram colocadas e discutidas as questões do lugar. O arquiteto Boucinhas esclareceu que, em 1994, optou por instalar seu escritório em uma das casas na própria Aldeia, percebendo que deste modo conseguiria maior relação com os residentes do lugar e abriria a probabilidade de acessar outros saberes além dos que informam os mapas. Explicou, também, durante as reuniões mensais feitas na escola que existe uma ligação muito forte dos moradores e da vizinhança com a Aldeia; suas relações vão surgindo, há estórias sobrenaturais, mistérios, milagres e também conflitos sobre o destino da Aldeia: uns desejam seja um centro turístico nacional; outros que que permaneça intocável, e outros, além disso, não se enfadariam se ela fosse demolida e a malha urbana vizinha passasse por cima de tudo. Existem também, os que a notam como área de valor histórico importante que precisa ser recuperada com sensibilidade e respeito: nela não cabe sofisticação, nem lampiões, nem vegetação - é um testemunho de um espaço jesuítico nascido neste lugar, naquele tempo, com funções claras - e hoje precisa que se criem qualidades para novos usos que contribuam para manter viva a Aldeia.

A diretora da escola Maria Helena Scabelo, disse que durante esse processo, também resultaram envolvidos moradores da região interessados em participar, debatendo o assunto e dando opiniões diversas. Organizaram-se reuniões que, depois de um ano, resultaram na criação da "Fundação Aldeia de Carapicuíba", da qual participaram, além de arquitetos/as, moradores de diferentes profissões, biólogos/as, pedagogos/as e também pessoas sem escolaridade. 
Naqueles anos, as crianças aproveitavam o pátio e seus arredores empinando pipas, jogando pião e bola de gude; os moradores só aos poucos iam confiando, mostrando e desvendando lugares esquecidos: "lá embaixo um lago onde a gente nadava: foram aterrando aos poucos e depois fizeram barracos por cima", "aqui tinha uma bica aonde todo mundo vinha buscar água, da boa"; Assim, ia-se descobrindo e catalogando caminhos e trilhas já existentes, novas perspectivas; o Pico do Jaraguá aparece inteiro a noroeste a partir dos fundos da Igreja, onde existia o cemitério, área mal-assombrada,; lá embaixo corre o Anhembi rumo ao Ribeirão Carapicuíba, na divisa com Osasco, afluente do Tietê. Os afluentes do Anhembi têm matas ciliares sombreando águas limpas que surgem através dos altos muros e gradis de condomínios fechados.

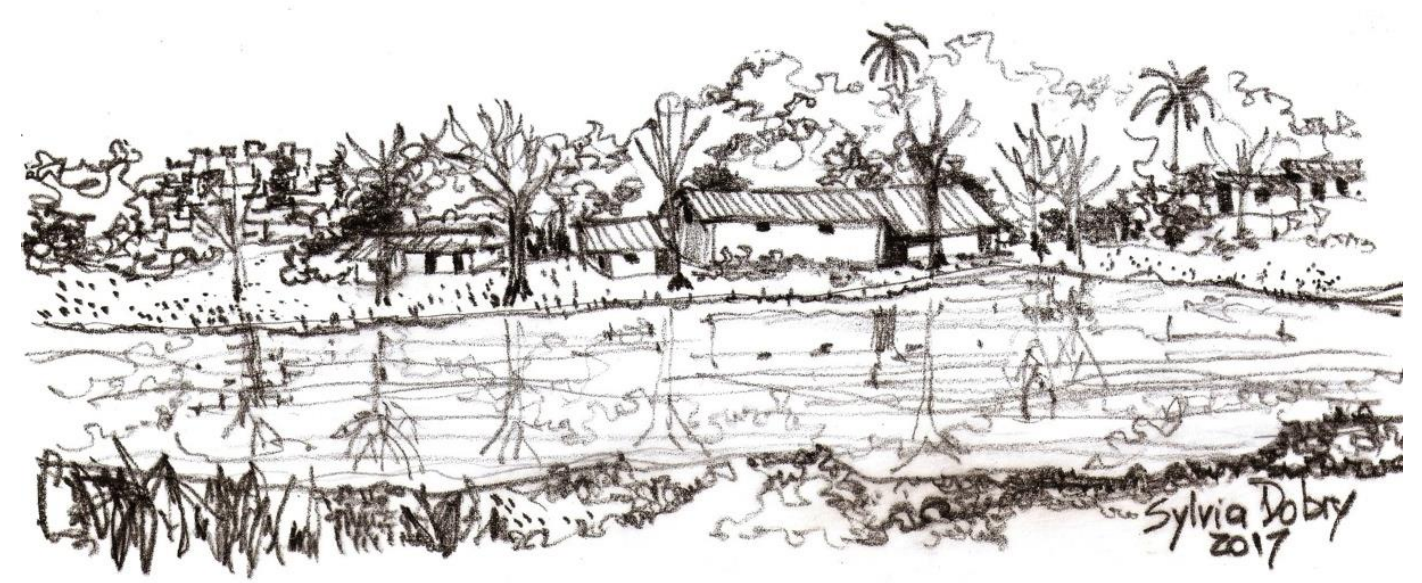

Figura 3. Entorno da Aldeia de Carapicuíba em 1998.

Croqui, em lápis sobre papel realizado por Sylvia A. Dobry /2017.

Desenvolveram-se, no entorno da Aldeia, loteamentos e condomínios fechados com grandes lotes na década de 1960, que foram sendo ocupados por pessoas que procuravam melhor qualidade de vida: muito verde, silêncio e paz, a $20 \mathrm{~km}$ da cidade de São Paulo. Perto da igreja, o antigo Sanatório Anhembi, atualmente, Faculdade da Aldeia de Carapicuíba (FALC) com $120.000 \mathrm{~m}^{2}$, estava na época abandonado, lugar de tráfico de drogas. Mas, também, aventuras: pelo buraco do muro tinha-se acesso a um mundo mágico de águas puras, nascentes, vegetação exuberante, escadarias, caminhos, capela, monumentos, e edifícios em ruínas.

Nos anos após 1997, a Aldeia cruzava um rápido processo de deterioração e presumia-se que receberia intensos impactos a partir da construção do "Rodoanel Metropolitano", cuja locação estava em debate, em diferentes instâncias.

Havia esperança sobre a atuação dos poderes públicos para a restauração das casas da Aldeia, que estavam em processo de deterioração, o estabelecimento de um parque no 
seu entorno e a valorização das suas tradições culturais - danças, cantos, violeiros, festas, ações que fazem parte de um território cultural.

Durante esse processo, que entrelaçava os vários níveis de ensino e disciplinas, aprofundou-se na reflexão e apropriação da história dessa aldeia e de seu valor como patrimônio histórico, tal como de seus problemas sociais e ambientais, que são próprios das periferias das grandes cidades da América Latina.

Embora tombada pelos órgãos de preservação, tanto do patrimônio federal (IPHAN), como estadual (CONDEPHAAT) e municipal e, mesmo especificando que qualquer obra, modificação ou reforma na aldeia e no entorno, num raio de 300 metros, só pode ser realizada com a aceitação desses órgãos, no entanto, estes não tinham condições de fiscalizar e manter os espaços e edificações sob controle.

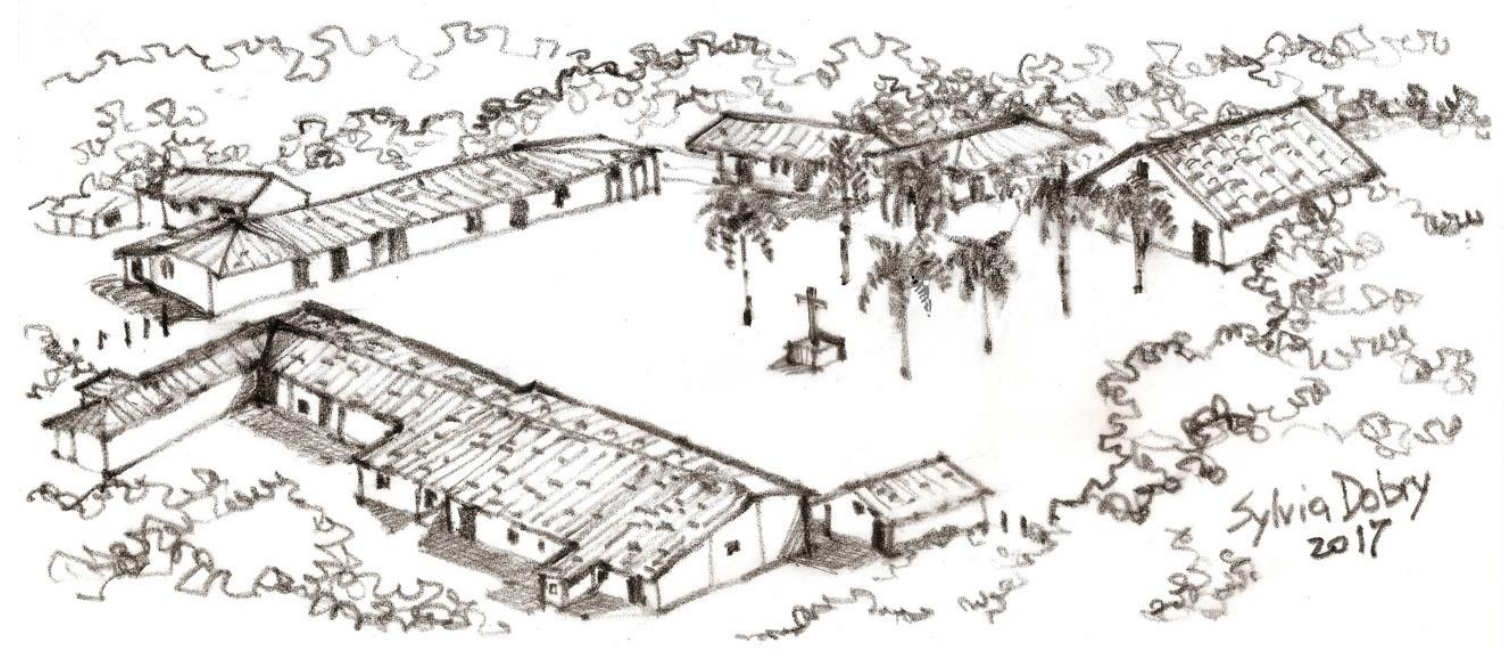

Figura 4. Croquis da Aldeia de Carapicuíba, em lápis sobre papel, realizada por Sylvia A. Dobry / $2017^{10}$

$\mathrm{Na}$ Aldeia, as instalações elétricas eram precárias, com risco de incêndio, o madeiramento dos telhados atacado por cupins e proliferam as ampliações nos fundos das edificações (puxadinhos), construídos clandestinamente, e as águas pluviais causam erosão no pátio. Todo tipo de uso era possível de visualizar na área protegida do entorno: áreas invadidas com habitações precárias, indústrias, pomares e hortas, estacionamento asfaltado. O pátio fazia parte da rota dos ônibus, ligando o Centro de Carapicuíba a São Paulo e Cotia, pela rodovia Raposo Tavares.

\footnotetext{
${ }^{10}$ Com base nos estudos de Luís Saia Luis , que fez o primeiro estudo sobre a Aldeia em 1938, durante a gestão de Mario de Andrade.(Fonte: ANDRADE [2006, p. 24], apud FACCIO, Neide Barrocá ,2010, p. $60)$.
} 
É importante esclarecer algumas ideias em relação à cultura e à arte, por abrangerem o tema proposto para reflexão neste artigo.

\section{Vivências, Poéticas e Registros,}

As palavras cultura, culto e colonização têm a mesma gênese etimológica que deriva

[...] do mesmo verbo latino colo, cujo participio passado é cultus, seu particípio futuro, culturus.

Colo significou, na língua de Roma, eu moro; eu ocupo a terra; eu trabalho; eu cultivo o campo. Um herdeiro antigo de colo é incola, o habitante; outro é inquilinus, aquele que reside em terra alheia. (BOSI, Alfredo, 1992, p. 11).

Segundo o autor, existe também outra relação etimológica: agrícola, palavra relacionada com trabalho, que mostra que desde sua origem há uma relação entre cultura e trabalho, o que leva a refletir sobre a pintura, a arquitetura, o urbanismo e a arte em geral, como parte da cultura, são também compreendidas no trabalho. ${ }^{11}$

Bosi, (1992, p.11), afirma que o verbete latino colo, do qual deriva a atual palavra cultura, anunciava as noções de tempo, espaço e movimento, basais nas artes plásticas, assim como na arquitetura e urbanismo. Tal termo acentua a relação de um sujeito com um objeto, no que diz respeito à ação de um arquiteto urbanista para um lugar, também considerado como território cultural e do desenhista, ou aquarelista, que alimenta sua criatividade nessa relação de espaço, tempo e movimento.

Por outro lado, colo é matriz de colônia, que exprime: "espaço que se está ocupando, terra e também povo que se pode trabalhar e sujeitar", (BOSI, Alfredo, 1992, p. 11). A frase, "povo que se pode trabalhar e sujeitar", do mesmo autor, resume toda a reflexão realizada em torno à ideia de cultura de massas, de colonização e dominação, implícita na Aldeia de Carapicuíba, vista como território cultural.

Em volta da gênese do termo "cultura", interessa, também, lembrar que a palavra latina colo, também significava "garra de atividade e poder imediato", o aqui e agora, e cultus refere-se ao passado: "é sinal de que a sociedade que produziu seu alimento já tem memória”. (BOSI, Alfredo, 1992, p. 13).

Isto leva a pensar na importância que tem a recuperação da memória dos lugares históricos vistos também como territórios culturais, ao contribuir para a sua formação,

${ }^{11} \mathrm{O}$ arquiteto e artista plástico Ubirajara Ribeiro, dizia nas suas aulas: "o importante é tentar fazer um trabalho sério, de qualidade e honesto; às vezes, este trabalho resulta em obra de arte". 
por meio de suas ações cotidianas e, como diz Merleau-Ponty ([1942], 2004, p.138): “[...] poderemos sempre descobrir em nosso passado o anúncio daquilo que nos tornamos".

Muitas vezes, existe um sentimento de não pertencimento a seus lugares de vida, em nossa visão, como parte da alienação gerada pela economia política que prioriza o valor de troca desses lugares sobre o seu valor de uso. É possível traçar um paralelo com a ideia de Foucault, (1979) de que o poder é uma relação de forças em constante movimento, considerando a alienação: também como uma relação de forças em que se abrem brechas pelas quais é possível transitar. Nessa relação de forças, o processo da arte pode contribuir, como um dos construtores da consciência e da percepção espacial, permitindo e abrindo a possibilidade do projeto participativo dos espaços públicos ou privados com o intuito da apropriação da cidade.

Descobrem-se em cultus duas definições: a primeira tem o sentido de culto; ritual feito em honra dos antepassados; enterro dos mortos; o que se trabalha sob a terra, e a segunda alude ao cultivado, o que foi trabalhado sobre a terra. Ao vincular os "dois significados desse nome-verbo que mostra o ser humano preso à terra e nela abrindo covas que o alimentam vivo e abrigam morto" (BOSI, Alfredo, 1992, p. 14 e 15), nasce a possibilidade de enraizar no passado a vivência presente de uma comunidade que se ergue através de mediações simbólicas, como: pintura, música, canto, gesto, dança, escultura, oração, a fala que evoca e a fala que invoca.

Nesse sentido, no Estudo do Meio, (a metodologia interdisciplinar de ensino utilizada), cujo enfoque era a arte, permitiu recuperar entre outras memórias de lendas indígenas retidas por transmissão via oral, a vivência da dança de Santa Cruz, que inspiraram as poesias das crianças, desenhos, maquetes, etc. Este processo de restauração da memória, se realizou primeiro nas reuniões conjuntas entre o grupo da pôs graduação da USP com a direção, professores/as e funcionários/as da escola, e depois por estes, através dos relatos de avós e pais dos alunos/as, e que foram apresentadas em exposições aos moradores em diversos lugares da Aldeia.

Recuperando o sentido de cravar no passado o presente de uma comunidade, as festas tradicionais na Aldeia de Carapicuíba mesclam elementos da cultura religiosa católica, negra e indígena. Em maio e em outubro, anualmente se realizam as festas tradicionais da Aldeia e, também, saem e chegam as romarias a cavalo para Santana do Parnaíba e Aparecida. As festas são feitas de cantorias, danças e comilança - a feijoada do sábado e a canja para os violeiros e seus acompanhantes na última madrugada. 
Existe na Aldeia de Carapicuíba a Associação dos Moradores, fundada em 1996, que participa nas proximidades das festas: músicas, cantorias, danças são aprendidas nos ensaios para as festas, enquanto são montados o pau-de-sebo e o mastro de São João. O movimento de caminhões, carros, ônibus vai rareando no começo da noite. Como a iluminação elétrica é deficiente no pátio contribui para um clima mágico, de mistério e calma, parecendo um lugar muito longe da agitação metropolitana.

O termo cultura, com o processo de urbanização, adequou também o sentido de condição de vida mais humana, mais ou menos conscientemente, por todas as classes e grupos, cujo sentido geral se mantém até hoje: “cultura é o conjunto das práticas, das técnicas, dos símbolos e dos valores que se deve transmitir às novas gerações para garantir a reprodução de um estado de coexistência social”. (BOSI, Alfredo, 1992, p. 16).

Essa ideia coexiste com outro conceito de cultura, vista como consciência de um presente com graves desequilíbrios, que preside a criação de alternativas para um futuro melhor, como afirma Bosi, (1992, p.16).

O processo de urbanização, porém, inclui deslocamento das pessoas, o que na Aldeia contribuiu para o apagamento da memória. Recuperar essa memória é, então, tarefa cultural que forma o elo entre passado, presente e futuro.

Nesse sentido, no contexto da experiência descrita, um dos professores de português, Valdomiro Rolim da Costa, realizou um belo trabalho de poesia com seus alunos da $6^{\mathrm{a}}$ série. Um deles escreveu:

Aldeia que se originou das cinzas dos índios.

Quase ninguém liga, que desespero!

Uma paisagem onde não se vê quase nada.

Uma aldeia perdida no ar da ignorância humana.

Desde começos do século XVI, a atenção que a ideia de cultura dava para o crescimento natural, estendeu-se ao processo de desenvolvimento humano, que junto ao significado de lavrar a terra, foi o sentido principal até inícios do século XIX, mais usado como metáfora. (WILLIAMS, Raymond, 2003, p.88.)

Tanto Bosi quanto Williams mostram que mudanças importantes produziram-se na transformação da palavra cultura, entre outras, a metáfora que se fez habitual. "A partir do século XVIII aproximam e, às vezes, fundem-se as noções de cultura e progresso" segundo Bosi, (1992, p.17). 
Cultura supõe uma consciência grupal trabalhadora que desentranha da vida presente e do passado os planos para o futuro; nesse sentido de projeto está implícito o mito de Prometeu, que arrancou o fogo dos céus para mudar o destino material dos homens. (BOSI, 1992, p.17).

Se por um lado, aculturar um povo se exprimiria em sujeitá-lo ou, adaptá-lo a certo padrão adequado para alguns interesses, por outro, "alguns traços formadores da cultura moderna, traços mais evidentes a partir da Ilustração, conferem à ciência, às artes e a filosofia um caráter de resistência, ou de possibilidade de resistência, às pressões estruturais dominantes em cada contexto." (BOSI, 1992, p.17). E é a partir disso que a professora Nidia Nacib Pontuschka disse no transcurso da experiência: "Este Estudo do Meio tem a arte como carro chefe", no contexto em que a arte em geral é muito pouco valorizada no currículo escolar. Isto ocorre tanto nos níveis de ensino primário, secundário quanto no ensino universitário, especialmente nos casos de cursos de graduação de Arquitetura e Urbanismo, nos que muitas vezes, se há diminuído a carga horária e até desparecido por completo em alguns casos, disciplinas tais como Desenho a mão livre ou Plástica. (Foge ao escopo deste artigo tratar especificamente deste assunto, mas se destaca a importância de se fazer uma pesquisa a respeito).

Como já dito anteriormente, entre as atividades do Estudo do Meio, incluía-se as oficinas de percepção do lugar através do desenho. Em decorrência dessas, houve alterações no processo criativo artístico individual, fruto do diálogo entre as diversas formas de expressão de cada participante. O entrelaçamento dos variados processos criativos e sua incorporação na criatividade individual colabora para pensar de forma mais ampla sobre a recuperação e formação da identidade de um lugar considerado como patrimônio histórico.

Tendo formação em arquitetura, disciplina em que a representação do real se faz importante com vista à construção de um lugar futuro e concreto, uma das formas de expressão dos autores, era a perspectiva a mão livre. Não pretendia-se, nas oficinas que se orientaram no contexto desta experiência, ensinar a desenhar. Apenas incentivar a exploração do espaço do desenho: abrir um pouquinho a cortina que cobre a janela para o mundo, ajudar a descortinar, a desvendar.

No processo metodológico do Estudo do Meio, um dos acontecimentos mais importantes, é "a saída a campo". Para isto, formávamos pequenos grupos, nos quais cada participante cumpriria diferentes funções.

Levamos material de desenho à mão livre para cada um dos participantes: papel sulfite A4, lápis de desenho de grafite macio, lápis de cores. Quando chegamos com esses 
instrumentos de desenho, muitos dos professores ficaram cativados, "sentindo-se artistas". Colocou-se como primeiro desafio não usar régua, o que provocou certa estranheza, mas foi aceito sem muita resistência.

Saímos da escola, de altos muros e cujo pátio era totalmente cimentado, sem jardim, mas extremamente acolhedora. Era um dia ensolarado, todos estavam com roupas confortáveis para fazer uma caminhada e fazer um reconhecimento do lugar. Partíamos em "excursão", levando pranchetinhas e, alguns, com câmeras fotográficas.

Caminhamos pela rua que liga a escola à praça e paramos em frente a uma árvore de flores laranja, a espatódea, e um dos arquitetos, paisagista e conhecedor de vegetação, explicou que essas flores matavam abelhas. Identificamos jerivás, ligustros, bananeiras, árvores de antigas chácaras, como a castanheira portuguesa e observamos construções irregulares perto da igreja.

Foi quando chegamos a uma praça, com uma igreja e uma cruz no centro, que a "saída a campo" transformou-se em oficina de percepção.

\section{Apropriação de lugares e de expressões: Formas de resistência}

\section{A visão do pintor é um continuo nascimento} Merleau Ponty ([1960], 2004, p. 22)

Ao exercer uma atividade criativa, como o desenho, experimenta-se um momento de introspecção. É um tempo para si, de reflexão sobre si mesmo e o mundo, expressamse sentimentos e pensamentos. Este é o tempo que o cotidiano da vida atual, na correria, na pressa e na concorrência pela eficácia, quase fez desaparecer. Esta falta de tempo próprio se relaciona diretamente com a falta de vivenciar e olhar a cidade, o lugar onde se pertence ou se transita.

O lugar, pensado como uma pausa no movimento, como afirma Tuan, (1980, p.06), na qual é possível gerar sentimentos que valorizam e criam o sentido do lugar, e à medida que se o conhece melhor, assumimos sentidos para a vida, permitindo, num constante reconhecimento, a sua identidade. Esse sentimento de afetividade em relação ao lugar convida as pessoas a agirem sobre o meio ambiente circundante.

Durante esse processo de construção de conhecimentos e de significados, pensamos que desenvolver a percepção do lugar, em especial, quando se trata de patrimônio histórico, seja um objetivo importante e para concretizá-lo, é necessário que 
a escola, entre outras instituições, dedique mais tempo e abra mais espaço às artes, que favorecem a construção do olhar.

Dessa forma, contribui-se no desenvolvimento do ser criativo, também visto como ser social, sujeito protagonista da história, ser pensante, crítico, que possa assumir com liberdade o desejo de um ambiente e de uma vida melhor.

O objetivo dessa oficina não era a produção de obras de arte, nem o aperfeiçoamento artístico dos participantes. Era, na verdade, uma vivência de curto tempo que permitisse uma abertura à percepção do lugar por meio do desenho. O objetivo dessa oficina era possibilitar a abertura desse espaço para que pudessem senti-lo como próprio, ter o direito a transitar pelos caminhos da arte. Por um lado, tinha-se claro que a oficina de percepção através do desenho, tinha a finalidade de abrir espaço para pessoas que, na sua maioria, tinham pouca vivencia nos caminhos da arte.

O modo de desenhar desses professores que, por muitos anos, tinham ficado distantes do desenho, chamou-nos a atenção. Vários autores sinalizam que o adulto que parou de desenhar, por exemplo, aos 10 anos, quando volta a fazê-lo, ainda que tivesse 40 anos, desenharia como se tivesse 10, mas ao apropriar-se novamente dessa expressão, em pouco tempo seu desenho cresce e amadurece.

Produzia-nos estranhamento ao observar alguns desenhos realizados como se o desenhista estivesse voando, vendo a praça desde cima, quadrada, e não desde o chão, em cuja visão o quadrado se transformaria numa figura trapezoidal. Isto trouxe a lembrança de Piaget, explicando que a criança desenha o que sabe que existe, e não o que vê. E nós pensávamos: estas professoras, adultas, desenham a praça quadrada, sabem que é quadrada, ainda que não a vejam quadrada; desenham com a mente, imaginam o que sabem e não veem o que está à sua frente.

A cruz no meio da praça não era desenhada vista desde cima, posicionava-se em vista frontal. Casas e igreja, quando vistas de cima, coerentemente com a visão assumida para a praça deveriam ser desenhadas a partir dos telhados. Porém, haviam provocado um movimento de rebatimento para mostrar as fachadas, sem profundidade. Os lados pareciam não existir: o desenho expressava uma mistura de posicionamentos do observador, de acordo com outra lógica: a importância dada aos elementos em sua relação com o conjunto. Também se notava que a proporção não atendia à realidade física. Nesses desenhos de aparência infantil, a dimensão simbólica cobrava uma importância maior. Em muitos desenhos, a igreja aparecia enorme, enquanto as casas enfileiradas em volta da praça pareciam pequenas formiguinhas, muito mais do que uma rápida contagem 
verificaria. A curiosidade e o diálogo que se estabeleceu, levaram-nos a valorizar e a pensar sobre esses desenhos como maneira de expressão.

A trajetória encaminhou-nos ao desenho de observação à mão livre e o trânsito pela arquitetura e urbanismo reforçou essa forma de expressão, onde técnica da perspectiva tem um peso importante. Para cumprir determinados objetivos, esta técnica é válida e não pode ser descartada, em especial no âmbito da criação de lugares, ou outras formas de arte, como cenografias, esculturas, etc.

Nesses casos, a representação pode ser considerada como mediação entre e imaginário e a realidade que queremos criar. E necessário enfatizar que existe uma intensa inter-relação entre o processo de criação e a representação da ideia. É esta última que permitirá a evolução da ideia projetual, seu desenvolvimento ate se concretizar em uma realidade. O desenho à mão livre, o croqui, para o arquiteto, longe de ser somente a ilustração da ideia, tem um papel formativo inserido no processo de construção da ideia.

A perspectiva à mão livre é uma das linguagens, entre as muitas formas de representação na arquitetura e urbanismo, com a intenção de comunicar mensagens, mas esta representação transforma-se significativamente, caso se trate de um artista plástico ou de um arquiteto urbanista. Por isto se considera que o desenho do arquiteto urbanista, do paisagista, do escultor, do desenhista industrial, entre outros, tem um compromisso com a realidade que também é física. Sua dimensão que, ainda que seja subjetiva, descobre mais ao objeto em si mesmo, tratando de captá-lo como ele é, diferenciando-se de uma fotografia. Neste caso, o desenho é um meio para uma criação tridimensional.

Em contrapartida, o desenho de um artista plástico, na pintura, na gravura, entre outras categorias artísticas, tem por desígnio principal expressar e comunicar, especialmente, suas emoções: trata-se de uma criação artística bidimensional. Muitas vezes, para conseguir comunicar determinadas sensações as regras da perspectiva são propositadamente distorcidas. Decidimos no contexto do estudo do meio realizado na Aldeia de Carapicuíba, em conjunto com os professores da EEPG Esmeralda Becker, experimentar outras maneiras de expressão, deixando de lado as regras da perspectiva, numa expressao livre, trabalhos que demandavam uma subsistência interior. Assim, ao mesmo tempo em que se postulava a recuperação do desenho como maneira de se apropriar do lugar, operava-se, outra maneira de expressar esta apropriação. O contato e diálogo com outras formas de expressão permitiram criar visões subjetivas memórias, narrativas, simbologias, medos e sonhos. 


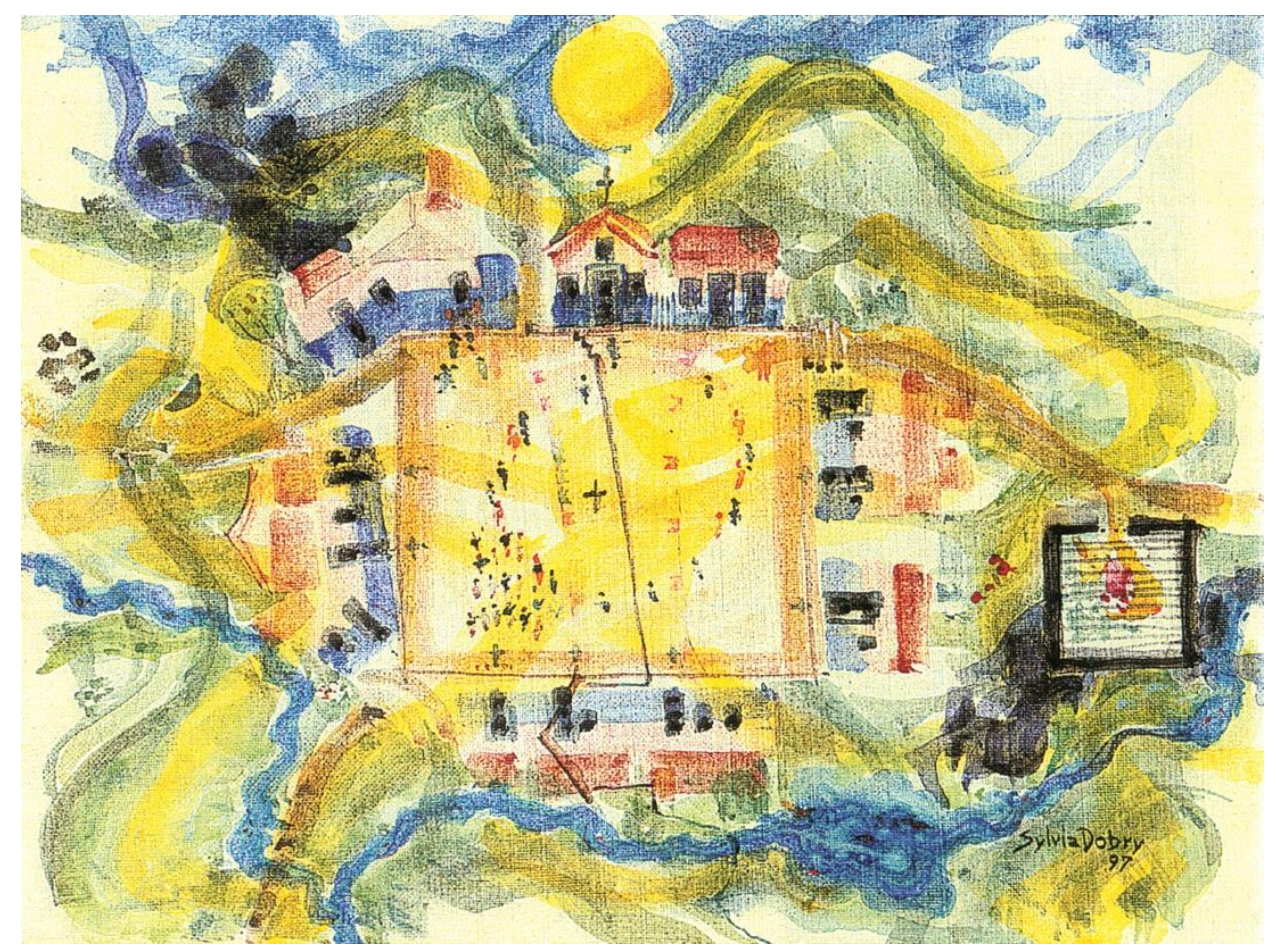

Fig.5 A festa na Aldeia de Carapicuíba, aquarela sobre tela, de Sylvia A. Dobry, 1997. Tamanho original $0.40 \times 0.30 \mathrm{~m}$.

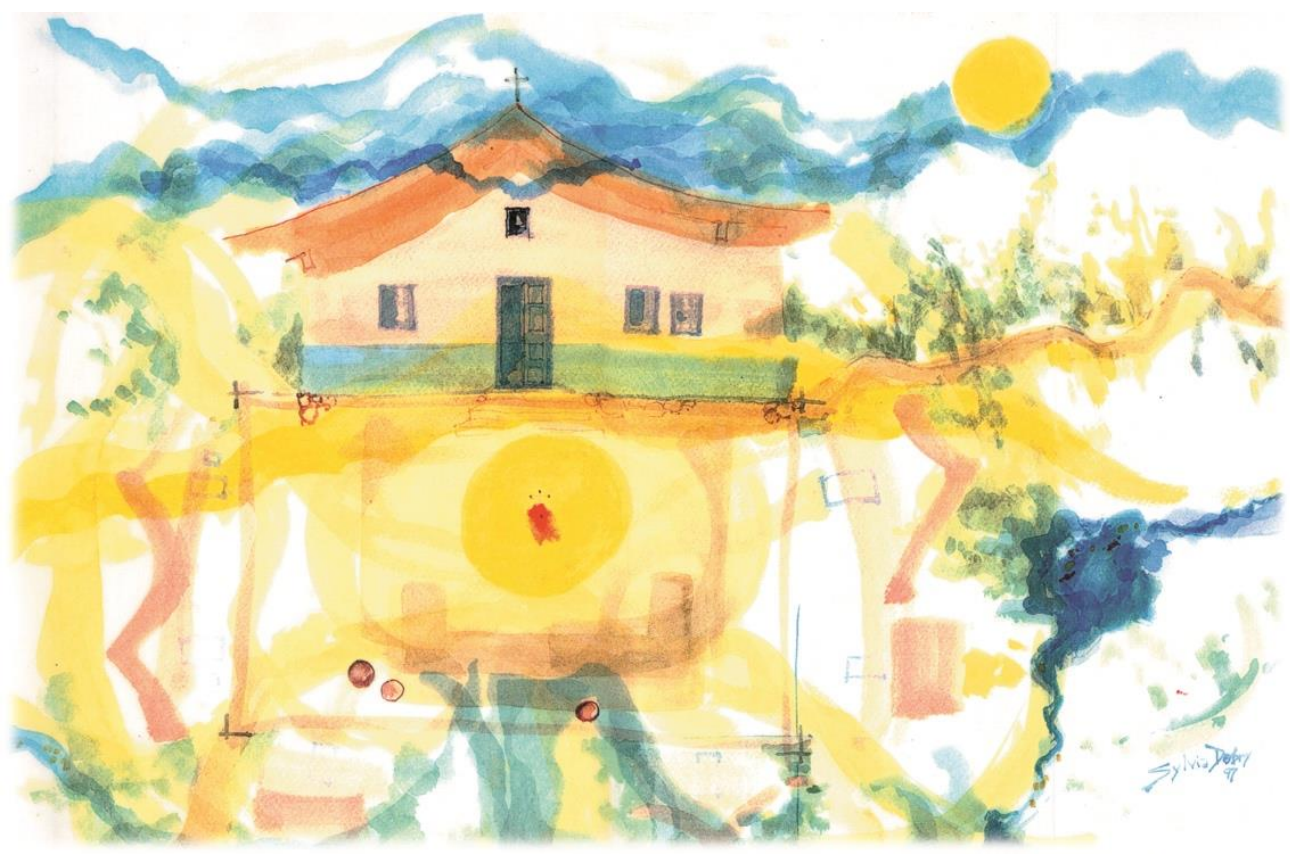

Fig.6. Igreja da Aldeia de Carapicuíba, aquarela de Sylvia Dobry, 1997. Tamanho original, $0.64 \times 0.45 \mathrm{~m}$.

Importante destacar que todo este processo descrito neste texto, contribuiu com o desenvolvimento do projeto de autoria do arquiteto Caio Boucinhas, iniciado em 1994 e implantado pela Prefeitura de Carapicuíba em 2004, com o nome de Parque Ecológico Aldeia de Carapicuíba e do qual se falará a seguir. 


\section{Parque Ecológico Aldeia de Carapicuíba: Projeto e Implantação}

Procurou-se harmonizar, no projeto do parque, os recursos naturais e a ocupação humana, considerando, a Aldeia Jesuítica de 1580 como também as residências nas áreas das nascentes. $\mathrm{O}$ projeto seguiu as seguintes premissas:

- Enfatizar a importância de um parque no entorno da Aldeia de Carapicuíba como cinturão protetor do patrimônio histórico e sua valorização, uma vez que preserva a eleição original do sitio;

- Restaurar as edificações tombadas da Aldeia;

- Vincular o parque público com a área rica em recursos naturais - flora, fauna, recursos hídricos - da grande chácara murada, onde estava sendo implantado, com apoio da prefeitura, um centro universitário.

- Abrigar atividades de turismo gastronômico, histórico, cultural (ateliers de arte, educação artística, capoeira, maracatu, esporte);

- Incentivar e valorizar a percepção do pedestre idealizando caminhos que conectem o ambiente histórico cultural com o ambiente natural.

Considerou-se a necessidade de estacionamento para carros sem impactar a estabilidade da Aldeia e de resolver as questões de drenagem de águas pluviais que esburacavam o pátio.

Durante os levantamentos e diagnósticos, vistorias e passeios com moradores, brotaram histórias de um antigo lago, nascentes de onde tiravam água para beber. Foi combinado com moradores e técnicos que as casas próximas às nascentes deveriam ser retiradas, e o projeto contemplou a realização de dois lagos. Porém foi executado até 2016 apenas o lago da nascente, e não o que aproveitava a água do córrego e abrigava um deque, palco de um teatrinho/cinema ao ar livre. O projeto desse lago levou em consideração a topografia: a arquibancada/plateia do palco/deque sobre o lago desenvolvia-se no suave talude existente.

Em relação ao projeto de plantio, predominaram árvores nativas, preservando as árvores existentes, de origem portuguesa, que foram reconhecidas na etapa de diagnóstico, como por exemplo, os pés de castanha portuguesa (Castanea sativa), testemunhas do período de colonização.

Foram executados, do projeto proposto: o piso do pátio central da Aldeia, com a drenagem de águas pluviais, o trecho sul do parque, a casa das atividades educativas e 
culturais - anexada a uma edificação tombada -, algumas trilhas, parte da vegetação prevista.

Ainda que seu projeto original tenha sido executado parcialmente, hoje, em 2016, o parque, considerado "imenso" por seus frequentadores, possui capacidade para 80 mil pessoas, tornando-se o principal local de diversão e recreação da população. Contêm ciclovias, playground, praça de eventos e pistas para caminhadas, que passam dentro de bosques ao redor do lago, mesas, bancos, churrasqueiras em lugares agradáveis para acomodar da melhor maneira os frequentadores. O espaço também é aberto para o comércio de vendedores ambulantes e para os artesãos da região expor seus trabalhos. Além disso, são armadas barracas de lanches, frutas, caldo de cana e outros alimentos.

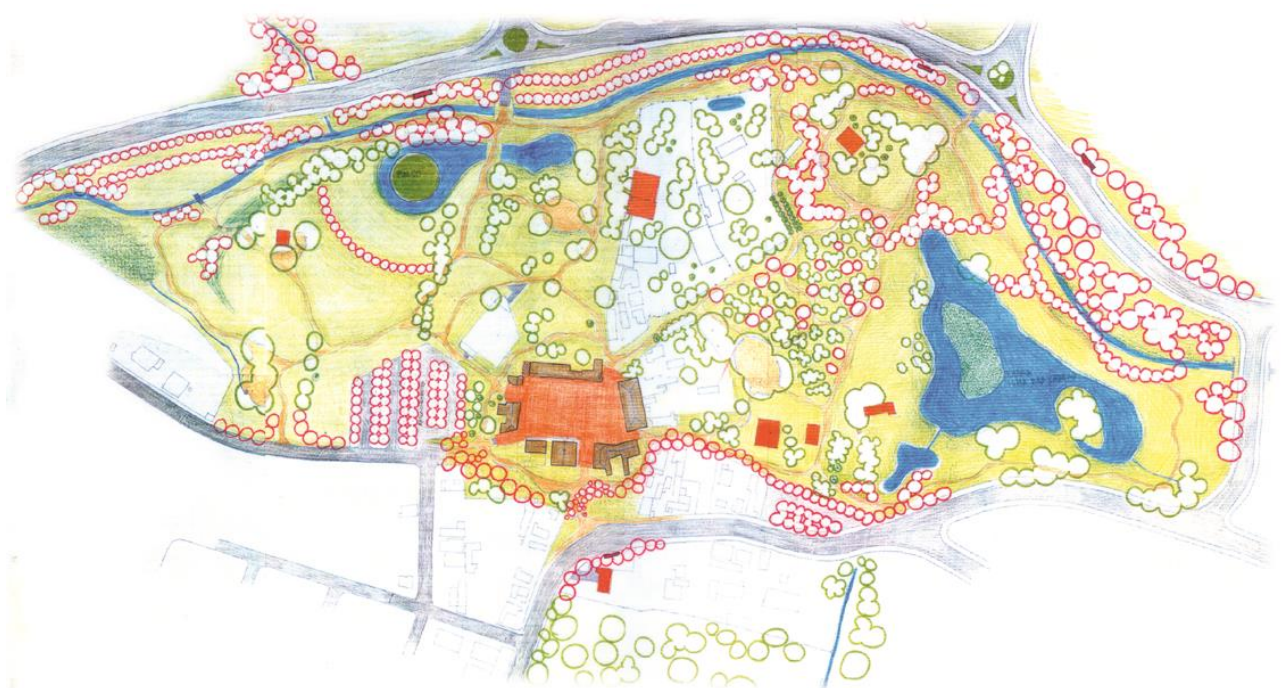

Figura 7. Anteprojeto para o Parque Ecológico Aldeia de Carapicuíba. Desenho de Caio Boucinhas, 1994.

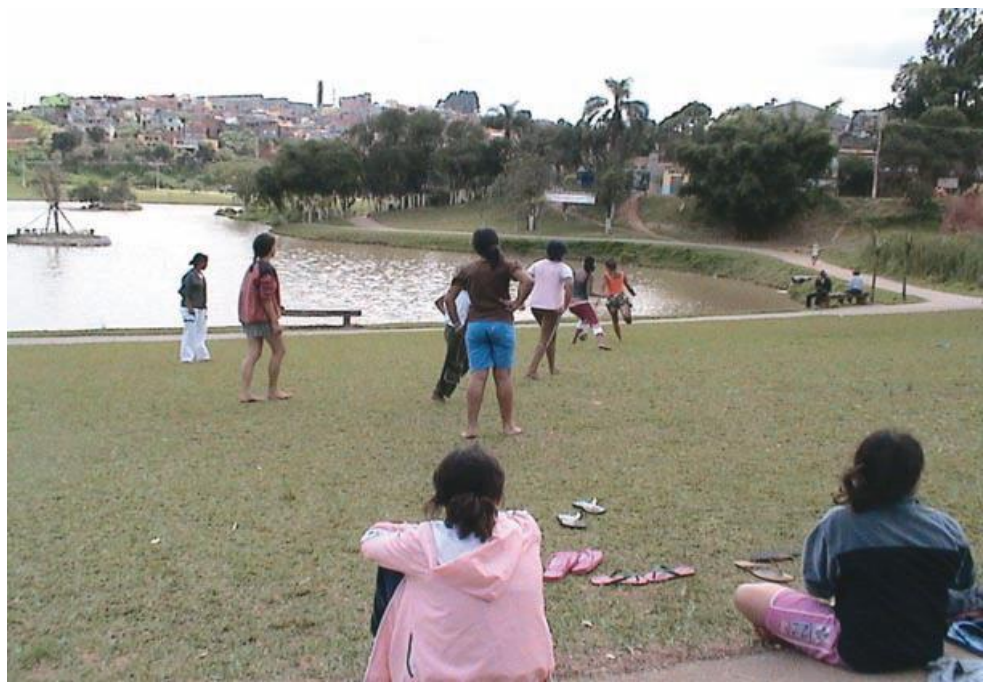

Figura 8. Trecho do parque implantado. Foto: Caio Boucinhas, fev. 2005. 


\section{Considerações Finais}

Esta experiência permitiu revelar o lugar, muitas vezes oculto, a cada um dos participantes.

Para professores/as e funcionários/as da escola significou descobrir o lugar cotidiano, descobrir significados mais profundos e valores culturais, o que possibilitou contribuir para a sua inserção na comunidade, e por sua vez, expandir horizontes de esperança na preservação e criação desses lugares.

Para os/as arquitetos/as participantes, significou estabelecer uma experiência de projeto arquitetônico paisagístico participativo, um diálogo com os verdadeiros usufruidores do lugar, entender suas aspirações e sonhos, abrindo a possibilidade da criação de lugares significativos, integrados ao cotidiano e, ao mesmo tempo, legíveis.

Na expressão particular artística, exprimiu a possibilidade de ampliar maneiras de expressão, o que significou maior liberdade de criação.

No caso apresentado se contemplaram três premissas: a arquitetura é um campo de caráter prioritariamente social; seu ensino deve partir da análise da sociedade e suas necessidades; sua gestão deve ser democrática e participativa, que corresponderam às experiências inovadoras de ensino de arquitetura e urbanismo dos anos 1060-70. Porém, esta experiência, como outras atuais que respondem a estas premissas, em geral estão relacionadas à extensão universitária, e/ou dentro do currículo formal, em disciplinas isoladas ou com poucas inter-relações. Por isto, do ponto de vista do ensino de arquitetura e urbanismo, áreas consideradas também como arte, encontrar lacunas para que possam cumprir um papel reflexivo e ativo, foi uma proposta interdisciplinar, desenvolvida na Aldeia de Carapicuíba. Não é possível ignorar que "a arte se move no interior de um sistema que produz a alienação".

Nessa contradição complexa, entende-se que a presença da arte simboliza pontes a horizontes mais extensos de reflexão, percursos que possam provocar-mudanças internas nas pessoas que por eles transitam. $\mathrm{O}$ trabalho com a arte, a percepção e o desenho podem ser um dinâmico recurso que transforma aquele que vê e o que é visto, ao mesmo tempo. Do mesmo modo que o ato de desenhar acentua o olhar e contribui para a educação da própria sensibilidade. Desenhar um lugar, sob diferentes miradas, aprimora a percepção das relações espaciais, ampliando as possibilidades para se refletir sobre a dinâmica social e histórica ali impressa. Atividades incluídas na arte e a criatividade podem possibilitar o estabelecimento de sintonias com a paisagem, aprofundando a 
relação cognitiva com os lugares. Nestas ações coletivas, o uso de linguagens artísticas entre os participantes, proporciona a abertura das maneiras como os lugares são apreendidos e ao mesmo tempo contribui para o desenvolvimento das possibilidades de agir sobre estes espaços e sobre suas representações. Na nossa visão, isto é importante, no intuito de alargar e aprofundar as probabilidades de criação de lugares significativos, legíveis e integrados ao cotidiano. Expandiram-se as perspectivas na preservação histórica e ambiental e criação desses lugares, confirmadas pela implantação do projeto do parque - hoje com o nome de Parque Ecológico da Aldeia de Carapicuíba -, ainda que parcialmente em relação ao projeto original, realizado pela Prefeitura, o que só foi possível pelo envolvimento direto da comunidade.

\section{Referências}

BARCELLOS, João. Os Jesuítas na Terra dos Brazis. In: Revista A Página da Educação. № 173. Ano 16. Dezembro 2007. Disponível in: http://www.apagina.pt $/$ ?aba $=7 \&$ cat $=173 \&$ doc $=13084 \& \operatorname{mid}=2$ data acesso $24 / 06 / 2013$.

BOSI, Alfredo. Dialética da Colonização. São Paulo: Companhia das Letras, 1992.

BOUCINHAS, Caio. Projeto Participativo na produção do espaço público. São Paulo: Tese de Doutorado. FAU-USP, 2005.

BURNICHON, María Saleme. Entrevista realizada en junio de 1996 e publicada no suplemento digital da revista "La Educación en nuestras manos" ( $\mathrm{N}^{\circ} 23$; septiembre de 2005), del Sindicato Unificado de Trabajadores de la Educación de la Provincia de Buenos Aires. Disponível in: http://haciendorondas.blogspot.com.br/2015/09/ensenar-esaprender-escuchar-by-maria.html acesso em: 27/11/2017.

Decires. "Decires”. Córdoba. Narvaja Editor. 1997

DOBRY-PRONSATO, Sylvia Adriana. Arquitetura e Paisagem: projeto participativo e criação coletiva. São Paulo: Annablume/ Fapesp/Fupam, 2005.

FACCIO, Neide Barrocá. A Aldeia Carapicuíba e sua resolução de tombamento. In Topos, vol. 4, $\mathrm{n}^{\circ}$ 2, 2010. Disponível em: http://revista.fct.unesp.br /index.php/topos/article/viewFile/2255/2064. Acesso em: 26 jun. 2014.

LIMA, Mayumi Watanabe de Souza. A cidade e a criança. São Paulo: Nobel, 1989.

MERLEAU-PONTY, Maurice. A dúvida de Cézanne. In: O olho e o espírito. Trad. Paulo Neves e Maria E. Galvão Gomes Pereira. São Paulo: Cosac \& Naify, 2004. (Texto original publicado em 1942)

Fenomenologia da percepção (C. Moura, Trad.). São Paulo: Martins Fontes. 1994 (Texto original publicado em 1945)

O olho e o espírito.. Trad. Paulo Neves e Maria E. Galvão Gomes Pereira. São Paulo: Cosac \& Naify, 2004. (Texto original publicado em 1960) 
OLIVEIRA, Marilza de. Para a história social da língua portuguesa em São Paulo: séculos XVI-XVIII. Disponível em: http://www.fflch.usp.br/dlcv/lport/pdf/maril011.pdf Data acesso: $24 / 05 / 2012$.

RODRIGUES Jacinto. Joseph Beuys um filósofo na arte e na cidade. In Millenium'revista do ISPV-n ${ }^{\circ}$ 25- Janeiro de 2002, disponível in: http://repositorio.ipv.pt /bitstream/10400.19/642/1/JOSEPH\%20BEUYS.pdf acesso 24/11/2017

STACHELHAUS, Heiner, "Joseph Beuys", Ed. Parsifal, Barcelona, 1990

TUAN, Yi-Fu. Topofilia: um estudo da percepção, atitudes e valores do meio ambiente. São Paulo: Ed. DIFEL, 1980.

ZAHN, Carlos Eduardo; FEITOSA, Maria José; SAWAYA, Sylvio Barros. "Aldeia de Carapicuíba: estudo histórico, arquitetônico e urbanístico do único aldeamento jesuítico paulista remanescente". In: Revista ECCOS, n 001, v.02. São Paulo: Ed. Centro Universitário Nove de Julho, 2000.

WILLIAMS, Raymond. Palabras - clave: un vocabulario de la cultura y la sociedad. Buenos Aires: Ed. Nueva Visión, 2003. 



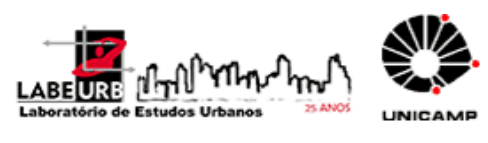

\section{Para citar essa obra:}

DOBRY, Sylvia Adriana Dobry; BOUCINHAS, Caio e PESSOA, Denise Falcão. Participação, arte e vivencias num território cultural. In: RUA [online]. $n^{\circ}$. 24. Volume 1 - p. 139-163 - e-ISSN 2179-9911 - junho/2018. Consultada no Portal Labeurb Revista do Laboratório de Estudos Urbanos do Núcleo de Desenvolvimento da Criatividade.

http://www.labeurb.unicamp.br/rua/

Capa: A festa na Aldeia de Carapicuíba, aquarela sobre tela, de Sylvia A. Dobry, 1997. Tamanho original $0.40 \times 0.30 \mathrm{~m}$.

\section{Laboratório de Estudos Urbanos - LABEURB}

Núcleo de Desenvolvimento da Criatividade - NUDECRI

Universidade Estadual de Campinas - UNICAMP

http://www.labeurb.unicamp.br/

\section{Endereço:}

LABEURB - LABORATÓRIO DE ESTUDOS URBANOS

UNICAMP/COCEN / NUDECRI

CAIXA POSTAL 6166

Campinas/SP - Brasil

CEP 13083-892

Fone/ Fax: (19) 3521-7900

Contato: http://www.labeurb.unicamp.br/contato 